\title{
Bimbingan Kelompok Teknik Group Exercise untuk Mengembangkan Self Disclosre Peserta Didik
}

\author{
The Group Guidance of Group Exercise Technique to Develop Self Disclosure \\ of the Students
}

\author{
Haiatin Khasanatin, Nandang Rusmana \& Nandang Budiman \\ Universitas Pendidikan Indonesia, Bandung, Jawa Barat, Indonesia \\ haiatinkhasanatin@yahoo.com
}

\begin{abstract}
Abstrak
Penelitian ini dilatarbelakangi berdasarkan fenomena yang ada di MTs An-Nuur GUPPI Mojopahit Punggur Lampung Tengah yang menunjukkan adanya peserta didik yang memiliki self disclosure rendah. Tujuan penelitian ini menguji efektivitas bimbingan kelompok teknik group exercise untuk mengembangkan self disclosure peserta didik. Penelitian menggunakan pendekatan kuantitatif dengan metode eksperimen kuasi desain non-equivalent pretest-posttest countrol group. Sampel pada penelitian ini berjumlah 20 peserta didik kelas VIII. Teknik sampling yang digunakan adalah purposive sampling. Pengumpulan data melalui angket self disclosure dengan menggunakan skala likert. Hasil penelitian menunjukkan bahwa gambaran self disclosure kelompok eksperimen mengalami peningkatan setelah diberikan treatment. Sehingga dapat disimpulkan bahwa bimbingan kelompok teknik group exercise terbukti efektif untuk mengembangkan self disclosure peserta didik. Penelitianinimerekomendasikan kepada guru bimbingan dan konseling agar dapat melaksanakan program bimbingan kelompok teknik group exercise dan bagi penelitian selanjutnya untukdapat melakukan penelitian yang menguji teknik group exercise dengan subjek peserta didik SMA/SMK/MA maupun Mahasiswa dan dapat menggunakan strategi serta teknik bimbingan kelompok lainnya.
\end{abstract}

Kata kunci: self disclosure, bimbingan kelompok, group exercise

\begin{abstract}
This research is based on the phenomenon in MTs An-Nuur GUPPI Mojopahit Punggur Central Lampung which shows the existence of students who have low self disclosure. The purpose of this study is to test the effectiveness of the group guidance of group exercise technique to develop self-disclosure of the students. The study used a quantitative approach with a quasiexperimental design method of non-equivalent pretest-posttest control group. The sample in this study are 20 students of class VIII. The sampling technique used here is purposive sampling. Data collection was done through self disclosure questionnaire using Likert scale. The results showed that the self disclosure conception of the experimental group experienced improvement after treatment. The group guidanceofGroup Exercise technique was proven effective to develop self disclosure of the students. The recommendation of this research was shown to the guidance and counseling teacher in order to implement the group guidance program of group exercise technique, and for the subsequent research to conduct research that is testing the group exercise technique with the subject of high schoolstudents or even college students and could also utilize the other groupguidancestrategy and technique.
\end{abstract}

Keywords: self disclosure, group guidance, group exercise 


\section{PENDAHULUAN}

Perkembangan zaman yang pesat dan terusmenerus menawarkan perubahan, dan menuntut individu secara sadar atau tidak untuk meningkatkan kualitas hidupnya. Permasalahan demi permasalahan turut mengiringi perubahan yang terjadi di setiap sisi kehidupan. Permasalahan kehidupan sangatlah komplek, terutama permasalahn pribadi dan sosial. Manusia merupakan makhluk sosial yang selalu berhubungan dan membutuhkan orang lain dalam kehidupannya. Sebagai makhluk sosial, manusia tidak akan eksis tanpa adanya orang lain (Boeree, 2010). Menjalin hubungan dengan orang lain merupakan bagian yang tidak pernah lepas dari kehidupannya, manusia selalu berinteraksi dengan lingkunganya. Misalnya dalam lingkungan sekolah, peserta didik tidak dapat hidup sendiri tanpa teman, guru ataupun personil sekolah lainnya, untuk menunjang hal tersebut, diperlukan keterampilan sosial. Keterampilan sosial inimenunjang keberhasilan dalam bergaul serta syarat tercapainya penyesuaian sosial yang baik dalam kehidupan individu (Jourard, 1971). Individu yang memiliki keterampilan sosial yang tinggi cenderung mendapatkan penerimaan sosial yang baik, yakni menunjukkan ciri-ciri menyenangkan, bahagia dan memiliki rasa aman (Ifdil, 2013). Individu yang memiliki rasa aman pada umumnya memiliki kepercayaan diri yang tinggi dan merasa bebas untuk mengungkapkan pikiran, perasaan, dan kreatifitas. Sedangkan individu yang memiliki keterampilan sosial rendah, menunjukkan ciri-ciri kurang percaya diri, merasa tidak aman, tidak dapat mengekspresikan pikiran dan perasaannya secara bebas (Ifdil, 2013).

Tanpa self disclosure, individu cenderung mendapat penerimaan sosial kurang baik sehingga berpengaruh pada perkembangan kepribadiannya. Terlebih remaja, dimana masa remaja atau yang bisa disebut social hunger (kehausan sosial) yang ditandai dengan adanya keinginan untuk bergaul dan diterima di lingkungan kelompok sebayanya (peer group). Menurut Santrock (2007) masa remaja memiliki kecenderungan yang kuat untuk disukai dan diterima teman sebaya atau kelompok. Remaja akan merasa senang apabila diterima oleh kelompoknya, dan akan merasa sedih dan cemas apabila ditolak oleh kelompoknya. Lebih lanjut Santrock (2007) juga mengemuk akan bahwa remaja merasa senang untuk menghabiskan waktu dengan teman sepermainan dan meningkatkan minat remaja terhadap hubungan interpersonal. Remaja lebih cenderung tertarik dan terbuka untuk menceritakan permasalahannya kepada teman, atau menghabiskan waktu bersama dengan teman daripada dengan orang tuanya. Hal ini diperlukan self disclosure untuk menciptakan keakraban, dan menimbulkan rasa percaya diantara teman sebaya. Semakin tinggi self disclosure antar teman sebaya membuat semakin kecil kemungkinan terjadinya konflik yang terjadi, namun bukan berarti self disclosur yang sangat tinggi itu baik, namun harus ada batasan privasi yang diceritakan.

Self disclosure sendiri adalah pengungkapan reaksi atau tanggapan diri sendiri terhadap situasi yang sedang dihadapi serta memberikan informasi tentang masa lalu yang relevan untuk memahami tanggapan diri sendiri di masa kini tersebut (Supratiknya, 
2016). Senada dengan hal tersebut, keterbukaan diri merupakan hubungan yang mendalam dan saling memahami yang bersifat intim. Hal tersebut memudahkan individu untuk lebih dikenal dan merasa diterima, individu akan menemukan pengalaman yang menyenangkan dalam pernikahan yang harmonis atau hubungan persahabatan yang akrab. Hubungan yang didasari rasa percaya akan mengalahkan kecemasan dan merasa bebas untuk membuka diri tanpa merasa takut kehilangan afeksi dari pasangan atau sahabat. Hubungan semacam ini disebut dengan keterbukaan diri (self disclosure) (Myers, 2012). Dalam proses pembelajaran, sebagaimana disampaikan oleh Borshuk (2017) bahwa self disclosure siswa dapat menanamkan pembelajaran yang lebih mendalam sambil menghormati seluruh siswa di kelas.

Self disclosure menjadi suatu hal yang sangat penting diteliti karena menurut Devito (2010), terdapat beberapa fungsi dari self disclosure bagi individu, yaitu 1) Pengetahuan Diri yaitu perspektif tentang diri sendiri dan pemahaman yang lebih mendalam mengenai perilakunya. Jourard mengemukakan bahwa keterbukaan diri merupakan faktor penting dalam konseling dan psikoterapi, individu memerlukan keterbukaan diri karena melalui keterbukaan diri dapat memahami diri sendiri secara lebih mendalam; 2) Kemampuan mengatasi masalah terutama rasa bersalah yaitu memungkinkan individu untuk mampu menghadapi rasa bersalah, mengurangi atau bahkan menghilangkannya. Salah satu perasaan takut yang besar yang ada pada diri banyak orang adalah bahwa mereka tidak diterima lingkungan karena suatu rahasia tertentu, karena sesuatu yang pernah mereka lakukan, atau karena perasaan atau sikap tertentu yang mereka miliki; 3) Efisiensi Komunikasi yaitu membantu individu lebih memahami diri dan memahami orang lain. Yang menjadi salah satu persyaratan untuk membangun efektivitas komunikasi; 4) Kedalaman membina hubungan di mana membina hubungan yang bermakna dapat terjadi apabila pihak-pihak yang berhubungan saling melakukan self disclosure. Komunikasi antar pribadi yang dibangun akan menjadi komunikasi yang bermakna, yakni komunikasi pertukaran pergaulan, pertukaran kata, pertukaran pikiran, dan pertukaran dari hati ke hati.

Sebagai salah satu aspek penting dalam keterampilan sosial, self disclosure juga penting bagi remaja, karena remaja merupakan periode individu belajar menggunakan kemampuannya untuk memberi dan menerima dalam berhubungan dengan orang lain. Hal ini diperkuat dengan pendapat Havighurst (1997) yang mengemukakan bahwa "states that one of teenager development is achieving new better relation in a contemporary" yang berarti salah satu tugas perkembangan remaja yaitu mencapai hubungan baru yang lebih matang dengan teman sebaya. Sehubungan dengan karakteristik tersebut (mencapai hubungan matang dengan teman sebaya), kemampuan peserta didik dalam melakukan keterbukaan diri menjadi kontribusi penting dalam kesuksesan akademik dan interaksi dengan orang lain terutama teman sebaya, karena apabila remaja tersebut tidak memiliki kemampuan self disclosure, maka remaja tersebut akan mengalami kesulitan berkomunikasi dengan orang lain. Untuk kepentingan tersebut, penelitian ini ditujukan untuk menguji efektivitas 
bimbingan kelompok teknik group exercise untuk mengembangkan self disclosure peserta didik.

\section{METODE PENELITIAN}

Dalam penelitian ini menggunakan pendekatan kuantitatif, dengan desain quasi experimen atau eksperimental semu. Jenis desain eksperimen yang digunakan ialah non-equivalent pretest-posttest control group design. Dengan desain ini, baik kelompok eksperimen maupun kelompok kontrol dibandingkan, kelompok tersebut dipilih tanpa melalui rendomisasi, dua kelompok yang ada diberikan pre test kemudian diberi perlakuan dan yang terakhir diberi post test (Emzir, 2018). Penelitian dengan pendekatan ini menekankan pada data berupa angkaangka (numerical) yang pengolahan datanya dilakukan dengan metode statistik.

Desain penelitian yang digunakan digambarkan sebagai berikut:

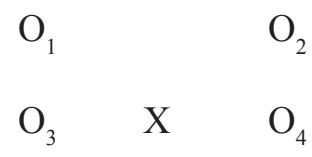

Gambar 3.1. Desain Penelitian(Houser, 2009)

Keterangan:

X : Treatmen yang diberikan

(Bimbingan kelompok Teknik GroupExercise)

- : Perlakuan Konvensional

$\mathrm{O}_{1}, \mathrm{O}_{3}:$ Pretest

$\mathrm{O}_{2}, \mathrm{O}_{4}$ : Posttest

KE : Kelompok Eksperimen

KK : Kelompok Kontrol

\section{HASIL DAN PEMBAHASAN}

\subsection{Hasil Penelitian}

Hasil pretest memberikan gambaran secara umum mengenai self disclosure peserta didik. Berikut dipaparkan gambaran umum self dislosure pada kelompok eksperimen dan kontrol dalam tabel 1 .

Tabel 1. Gambaran Umum Self Disclosure Peserta Didik Pretest

\begin{tabular}{cccccc}
\hline \multicolumn{2}{c}{ Kelompok Eksperimen } & \multicolumn{3}{c}{ Kelompok Kontrol } \\
\hline Kategori & $\sum$ & $\%$ & Kategori & $\sum$ & $\%$ \\
\hline Tinggi & 0 & $0 \%$ & Tinggi & 1 & $8 \%$ \\
\hline Sedang & 10 & $83 \%$ & Sedang & 9 & $75 \%$ \\
\hline Rendah & 2 & $17 \%$ & Rendah & 2 & $17 \%$ \\
\hline $\mathrm{N}$ & 12 & $100 \%$ & $\mathrm{~N}$ & 12 & $100 \%$ \\
\hline
\end{tabular}

Berdasarkan tabel 1 terlihat bahwa pencapaian self disclosure peserta didik pada kelompok eksperimen pencapaian pada kategori tinggi memperoleh hasil $0 \%$ yang berarti tidak ada peserta didik yang berada pada kategori tinggi, selanjutnya pencapaian pada kategori sedang 
memperoleh hasil 83\% (10 peserta didik), dan pada kategori rendah memperoleh hasil 17\% (2 peserta didik). Sedangkan pada kelompok kontrol mecapai tertinggi memperoleh hasil 8\% (1 peserta didik), selanjutnya untuk pencapaian pada kategori sedang yakni 75\% (9 peserta didik), dan pada kategori rendah memperoleh hasil 17\% (2 peserta didik). Berdasarkan hasil pretest dapat disimpulkan bahwa kelas eksperimen memiliki kecendrungan lebih rendah self disclosure-nya daripada kelas kontrol.

Sedangkan, hasil post test memberikan gambaran umum mengenai self disclosure peserta didik, baik kelompok eksperimen maupun kelompok kontrol, yang dapat dilihat pada tabel 2. di bawah ini.

Tabel 2. Gambaran Umum Self Disclosure Peserta Didik Post test

\begin{tabular}{cccccc}
\hline \multicolumn{2}{c}{ Kelompok Eksperimen } & \multicolumn{2}{c}{ Kelompok Kontrol } \\
\hline Kategori & $\sum$ & $\%$ & Kategori & $\sum$ & $\%$ \\
\hline Tinggi & 2 & $17 \%$ & Tinggi & 2 & $17 \%$ \\
\hline Sedang & 10 & $83 \%$ & Sedang & 7 & $58 \%$ \\
\hline Rendah & 0 & $0 \%$ & Rendah & 3 & $25 \%$ \\
\hline $\mathrm{N}$ & 12 & $100 \%$ & $\mathrm{~N}$ & 12 & $100 \%$ \\
\hline
\end{tabular}

Berdasarkan tabel 2 self disclosure peserta didik pada kelompok eksperimen mengalami peningkatan, terlihat bahwa pencapaian pada kategori tinggi memperoleh hasil 17\% (2 peserta didik) ada peningkatan $17 \%$ setelah diberikan treatment, selanjutnya pencapaian pada kategori sedang tetap yakni memperoleh hasil 83\% (10 peserta didik), dan pada kategori rendah memperoleh hasil $0 \%$ yang berarti tidak ada peserta didik yang berada pada kategori rendah. Sedangkan pada kelompok kontrol kategori tinggi juga mengalami peningkatan yang tadinya memperoleh hasil $8 \%$ (1 peserta didik) menjadi 17\% (2 peserta didik), selanjutnya untuk pencapaian pada kategori sedang yakni mengalami penurunan yang awalnya 75\% (9 peserta didik) menjadi $58 \%$ (7 peserta didik), dan pada kategori rendah mengalami peningkatan yang awalnya memperoleh hasil 17\% (2 peserta didik) menjadi 25\% (3 peserta didik).

Untuk mengetahui gambaran efektifitas bimbingan kelompok teknik group exercise untuk mengembangkan self disclosure peserta didik di MTs An-Nuur GUPPI Mojopahit Punggur Tahun Ajaran 2017/2018. Hasil pre test dan post test memberikan gambaran umum mengenai self disclosure peserta didik, baik kelas eksperimen maupun kelas kontrol, yang dapat dilihat pada gambar 1 dan 2 di bawah ini.

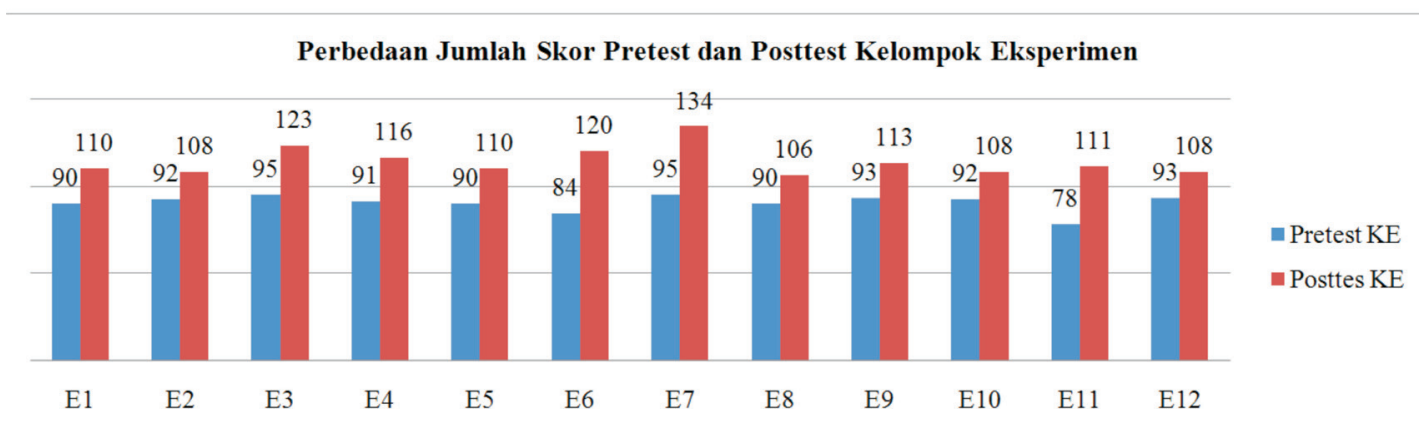

Gambar 1. Perbedaan Jumlah Skor Pretest dan Posttest Kelompok Eksperimen 
Gambar 1 menunjukkan perbedaan jumlah skor pre test dan post test pada kelompok eksperimen. Jumlah skor kelompok eksperimen mengalami peningkatan dari sebelum dan sesudah diberikan treatment bimbingan kelompok teknik group exercise, terlihat dari grafik skor jumlah skor pre test dan post test pada grafik di atas.

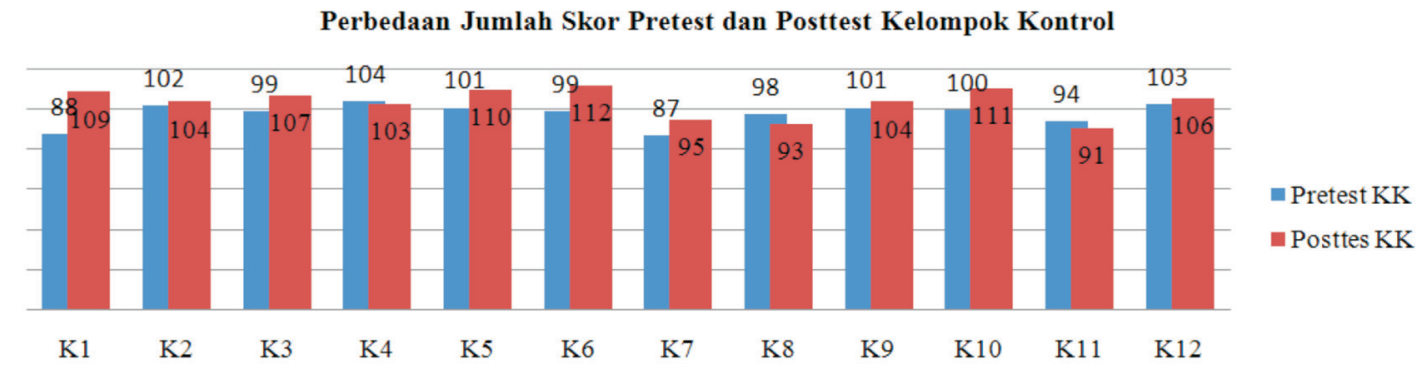

Gambar 2. Perbedaan Jumlah Skor Pre test dan Post test Kelompok Kontrol

Gambar 2 menunjukkan skor pretest dan posttest pada kelompok kontrol. Jumlah skor kelompok kontrol juga mengalami peningkatan dari skor pre test dan post test, namun ada juga yang mengalami penurunan dari pretest dan posttest, seperti peserta didik K4, K8 dan K11. Hal ini bisa juga dikarenakan pada kelompok kontrol tidak diberikan tretment berupa bimbingan kelompok teknik group exercise.

Pada gambar 1 dan 2 dapat dilihat pada skor pretest kelompok eksperimen lebih rendah dibanding skor pretest kelompok kontrol. Setelah diberikan intervensi bimbingan kelompok teknik group exercise pada kelompok eksperimen, kelompok eksperimen mengalami peningkatan $26 \%$, sedangkan kelompok kontrol hanya mengalami peningkatan sebesar $6 \%$. Bedasarkan hal tersebut, dapat dikatakan bahwa peserta didik kelompok eksperimen memiliki self disclosure lebih baik dibandingkan peserta didik pada kelompok kontrol, setelah peserta didik kelompok eksperimen diberi treatment.

\subsection{Pembahasan}

Sastama dkk (2017) mendefinisikan Self disclosure sebagai "Self disclosure is an attempt to let autheniticity enter our social relationships, and it is often liked with both mental health and self-concept development", yang berarti bahwa upaya untuk membiarkan keaslian memasuki suau hubungan sosial, dan sering dikaitkan dengan kesehatan mental dan pengembangan konsep diri. Self disclosure merupakan tindakan seseorang dalam memberikan informasi yang bersifat pribadi kepada orang lain secara sukarela dan disengaja untuk maksud memberi informasi yang akurat tentang dirinya. Rini (2009) mengungkapkan bahwa self disclosure adalah proses untuk membuat orang lain mengetahui tentang diri seseorang. Johnson (1981) mengungkapkan self disclosure dapat didefinisikan sebagai pengungkapan situasi sekarang dan memberikan informasi tentang masa lalu yang memiliki dua sisi, yaitu bersikap terbuka dengan yang lain dan bersikap terbuka bagi yang lain di manajika kedua proses ini dapat berlangsung secara serentak pada kedua belah pihak maka akan membuahkan relasi yang terbuka antar keduanya. Devito (2010) mendefinisikan self disclosure sebagai suatu jenis komunikasi 
yang mengungkapkan informasi tentang diri seperti pikiran, perasaan, pendapat pribadi yang biasanya disembunyikan dikomunikasikan kepada orang lain, serta memfasilitasi pengembangan dan pembentukan hubungan interpersonal (Bazarova \& Choi, 2014) yang tulus dan bermakna. Kana (2008) mengemukakan self disclosure adalah mengungkapkan reaksi atau tanggapan manusia terhadap situasi yang sedang dihadapi serta memberikan informasi tentang masa lalu yang relevan atau yang berguna untuk memahami tanggapan manusia di masa kini tersebut. Gusmawati dkk (2016) menjelaskan bahwa self disclosure merupakan proses menghadirkan diri yang diwujudkan dalam kegiatan membagi perasaan dan informasi dengan orang lain. Yakni proses berbagi yang dilakukan oleh sesorang kepada orang lain tentang berbagai hal dan informasi yang terkait dirinya dalam bentuk komunikasi. Beberapa ahli juga mendefinisikan self disclosure sebagai pengungkapan informasi secara lisan (Omarzu, 2000), dan sengaja tentang diri seseorang kepada orang lain (Raindkk, 2014), baik berupa pikiran, perasaan, maupun pengalamannya, sebagai pengembangan hubungan yang lebih dekat (Collins \& Miller, 1994). Dari penjelasan ahli di atas, yang dimaksud self disclosure adalah sikap individu dalam membagikan informasi yang bersifat pribadi, seperti perasaan, pikiran, dan keinginan, kemudian dikomunikasikan kepada orang lain secara sukarela, sehingga memunculkan hubungan yang lebih intim atau akrab.

Pada penelitian ini, peningkatan self disclosure ditandai dengan ketercapainya setiap peserta didik dalam memenuhi keenam aspek self disclosure yang sebagaimana disampaikan Jourard (1971a), yaitu aspek sikap/opini, aspek selera dan minat, aspek pendidikan, aspek keuangan, aspek kepribadian, dan aspek fisik. Ifdil (2013) menjelaskan keenam aspek self disclosure tersebut sebagaimana berikut:

1. Sikap atau opini (attitudes or opinions), mencakup informasi sikap dan pendapat mengenai keagamaan, dan pergaulan remaja.

2. Selera dan minat (tastes and interests), mencakup informasi tentang selera dalam berpakaian, makanan, dan kegemaran akan hobi yang disukai.

3. Pendidikan (studies), mencakup informasi keadaan lingkungan sekolah, dan pergaulan sekolah.

4. Keuangan (money), mencakup informasi tentang sumber keuangan, pengeluaran yang dibutuhkan, dan cara mengatur keuangan.

5. Kepribadian (personality), mencakup informasi tentang hal-hal yang mencakup keadaan diri, seperti marah, cemas, sedih, serta hal-hal yang berhubungan dengan lawan jenis.

Peningkatan self disclosure juga terlihat pada peningkatan aspek, yaitu pada 1) aspek sikap atau opini, kenaikan persentase skor sebesar $13 \%$, dimana persentase skor pre test sebesar 58\%, dan persentase skor post test sebesar 71\%. Pada aspek selanjutnya yaitu 2) aspek selera dan minat kenaikan persentase skor sebesar 9\%, dimana skor awal yaitu persentase skor pre test sebesar $58 \%$, dan persentase skor persentase post test sebesar 67\%. 3) Pada aspek pendidikan, 
kenaikan persentase skor sebesar $12 \%$, dimana persentase skor pre test sebesar $62 \%$, dan persentase skor post test sebesar $74 \%$. Selanjutnya pada 4) aspek keuangan, kenaikan persentase skor sebesar $8 \%$, dimana persentase skor pre test sebesar 58\%, dan persentase skor post test sebesar 66\%. 5) Pada aspek kepribadian, kenaikan persentase skor sebesar 5\%, dimana persentase skor pre test sebesar $61 \%$, dan persentase skor post test sebesar 66\%. Dan yang terakhir 6) aspek fisik, kenaikan persentase skor sebesar $6 \%$, dimana persentase skor pre test sebesar $56 \%$, dan persentase skor post test sebesar $62 \%$. Hal tersebut didukung dari penelitian Veletsianos $\&$ Stewart (2016) yang menyebutkan bahwa temuan tentang self disclosure berfungsi sebagai pengingat kompleks lingkungan yang dipelajari para sarjana kontemporer dalam berinteraksi. Self isclosure dianggap sebagai keterampilan kunci dalam konseling (Phillips dkk, 2018). Tidak semua individu memiliki kemampuan untuk mengungkapkan permasalahannya atau yang disebut self disclosure, self disclosure muncul karena hasil interaksi dengan lingkungannya, pola asuh orang tua dan pengalaman yang didapatkannya (Setianingsih dkk, 2014). Jourard berpendapat keterbukaan dalam suatu hubungan adalah prasyarat untuk kepribadian yang sehat (Derlega \& Berg, 1987). Hal ini senada dengan pendapat Derlegadkk (2006) yang menyembutkan bahwa melalui self disclosure memungkinkan individu dapat melepaskan diri dari himpitan beban psikologis misalnya stress dan depresi, sehingga dapat disimpulkan bahwa individu yang terbiasa melakukan self disclosure relatif terlepas dari penyakit-penyakit psikologis tersebut. Mengingat keterbukaan diri akan menimbulkan reaksi keintiman, karena keterbukaan diri merupakan dasar bagi hubungan yang sehat, semakin bersikap terbuka kepada orang lain, orang lain pun akan sebaliknya terbuka dan akan tercipta relasi yang lebih akrab. Hal ini senada dengan pendapat Jourard (1971), pentingnya self disclosure dalam hubungan dekat adalah mengenali lebih dalam (Tokic, 2010).

Peningkatan self disclosure menurut Devito (2010) dipengaruhi oleh beberapa faktor yaitu: 1) Besar Kelompok di mana keterbukaan diri lebih banyak terjadi dalam kelompok kecil daripada kelompok besar. Diad atau yang disebut kelompok kecil yang terdiri dari dua orang merupakan lingkungan yang paling cocok untuk keterbukaan diri. Dengan satu pendengar, pihak yang melakukan keterbukaan diri dapat meresapi tanggapan dengan cermat; 2) Perasaan Menyukai. Individu akan membuka diri kepada orang yang ia suka atau cintai dibandingkan kepada orang yang ia tidak sukai, ini karena orang yang tidak kita sukai dapat memberikan dukungan dan tanggapan yang positif. Orang yang disukai tentunya merupakan seseorang yang sangat dipercaya dan bisa menjaga rahasia yang dibagi, dan biasanya orang yang disukai sudah lama dikenal; 3) Efek Diadik. Individu melakukan keterbukaan diri apabila orang yang bersamanya melakukan keterbukaan diri juga, dikarenakan efek diadik ini membuat individu tersebut lebih aman dan dapat memperkuat perilaku keterbukaan diri. Individu akan mulai terbuka bila ia sudah menaruh kepercayaan dan yang paling penting adalah orang lain mau terbuka juga 
tentang informasi pribadinya. 4) Kompetensi. Individu yang mempunyai kompetensi lebih banyak melakukan keterbukan diri daripada orang yang kurang mempunyai kompetensi, ini dikarenakan orang yang mempunyai kompetensi biasanya mempunyai kepercayaan diri yang tinggi sehingga lebih ingin berbagi banyak hal-hal yang positif yang dimilikinya, biasanya orang yang mempunyai kompetensi akan membaginya kepada orang yang kurang mempunyai kompetensi. 5) Kepribadian. Individuindividu yang pandai bergaul (sociable) dan mempunyai kepribadian extrovert lebih banyak membuka diri mereka dari pada individu yang kurang pandai bergaul dan mempunyai kepribadian introvert. Individu yang mudah bergaul dengan siapapun akan mempunyai banyak teman dan lebih sering terjadinya interaksi dan komunikasi, banyak dari mereka mempunyai kemampuan berbicara di depan umum dengan baik dan dengan nyaman bertukar informasi. 6) Topik. Individu akan lebih sering membuka diri dengan topik tertentu daripada topik yang lainnya, individu umumnya lebih sering mengungkapkan tentang pekerjaan, hobi, cita-cita, dan pergaulan daripada mengungkapkan tentang kehidupan seks, dan informasi yang buruk, ini dikarenakan semakin pribadi dan negatif semakin kecil pula individu akan terbuka. 7) Jenis Kelamin. Peran gender sangat berpengaruh dalam self disclosure, laki-laki lebih tertutup dibandingkan perempuan. Perempuan lebih terbuka, intim dan penuh emosi. Perempuan maskulin, relatif kurang membuka diri ketimbang perempuan yang nilai dalam skala maskulinitasnya lebih rendah. Sebaliknya laki-laki feminin membuka diri lebih besar ketimbang lai-laki yang nilai dalam skala feminitasnya lebih rendah.

\section{SIMPULAN}

Berdasarkan hasil penelitian, dapat disimpulkan bahwa bimbingan kelompok teknik group exercise terbukti efektif untuk mengembangkan self disclosure peserta didik. Sehingga peneliti merekomendasikan ada penelitian selanjutnya untuk mengembangkan intervensi bimbingan kelompok teknik group exercise pada peserta didik SMA/SMK/MA maupun Mahasiswa, mengembangkan variabel penelitian berdasarkan aspek kebutuhan psikologis peserta didik, menggunakan strategi dan teknik bimbingan kelompok yang lain seperti sosiodrama, psikodrama, permainan, modelling, dan sebagainya, menggunakan angket dengan skala guttman, skala thurstone, skala diferensial, dan skala rating scale, menggunakan jenis-jenis group exercise lain seperti feedback (umpan balik), movement (gerak), creative props, arts and crafts, fantasy, trust (kepercayaan), experiential, moral dilemma (dilema moral), group-decision (keputusan kelompok), dan touching (sentuhan).

\section{DAFTAR RUJUKAN}

Bazarova, N. N \& Choi, Y. H. (2014). Self-Disclosure in Social Media: Extending the Functional Approach to Disclosure Motivations and Characteristics on Social Network Sites. Journal of Communication, 1-23.

Boeree, C. G. (2010). Personality theories. Jogjakarta: Prismasophie. 
Borshuk, C. (2017). Managing Student Self-Disclosure in Class Settings: Lessons from Feminist Pedagogy. Journal of the Scholarship of Teaching and Learning, 17 (1), hlm. 78-86.

Collins, N. L., \& Miller, L. C. (1994). Self-disclosure and laking: a meta-analytic review. Psychological Bulletin, 116 (3), hlm. 457-475.

Derlega, V. J \& Berg, J. H. (1987). Self Disclosure Theory, Research, and Therapy. New York: Springer ScienceBusiness Media, LLC.

Devito, J. A. (2010). Komunikasi Antara Manusia. Jakarta: Karisma Publishing.

Emzir. (2018). Metodologi Penelitian Pendidikan: Kuantitatif dan Kualitatif. Jakarta: Rajawali Pers.

Gusmawati, Taufik \& Ifdil. (2016). Kondisi Self Disclosure Mahasiswa Bimbingan dan Konseling. Jurnal Konseling dan Pendidikan, 4 (2),hlm. 92-97.

Havighurst, R. J. (1997). Human Development and Education. New York: David Mckey.

Houser, R. (2009). Counseling and Educational Research. United States of America: SAGE Publications, Inc.

Ifdil. (2013). Konsep Dasar Self Disclosure dan Pentingnya bagi Mahasiswa Bimbingan dan Konseling. Jurnal Ilmiah Ilmu Pendidikan, Vol XIII No 1 April 2013. Fakultas Ilmu Pendidikan Universitas Padang.

Johnson, D. W. (1981). Reaching Out Interpersonal Effectiveness and Self Actualization. USA: Prentice-Hall, Inc.

Jourard, S. M. (1971a). Self-Disclosure: an Axperimental Analysis of the Transparent Self. New York: WileyInterscience.

Jourard. S. M. (1971). Self disclosure; an experimental analysis of the transparent self. New York: Publishing Company Huntington (edisi terjemahan oleh Dedy Mulyana).

Kana. (2008). Keterbukaan diri pada janda cerai yang mencari pasangan melalui internet. (Skripsi). Universitas Gunadarma.

Myers, D. G. (2012). Psikologi Spsial. Jakarta: Salemba Humanika.

Omarzu, J. (2000). A disclosure decision model: determining how and when individuals will self-disclose. Journal Personality and Social Psychology Review, Vol. 4, No. 2, 174-185.

Rain, S. A., Brunner, S, R \& Oman, K. (2014). Self-disclosure and new communication technologies: The implications of receiving superficial self-disclosures from friends. Journal of Social and Personal Relationships 2016, 33(1), hlm. 42-61.

Rini, I. R. S. (2009). Hubungan antara keterbukaan diri dengan penyesuaian perkawinan pada pasangan suami istri yang tinggal terpisah. Journal Psycho Idea, 7 (2), hlm. 1693-1076.

Santrock, J. W. (2007). Remaja (Edisi 11 Jilid 2). Jakarta: Erlangga.

Sastama, G. D., Muslim, M \&Djannah, W. (2017). Keefektifan homeroom untuk meningkatkan keterbukaan diri siswa SMP. Jurnal Program Studi Bimbingan dan Konseling, 5 (1), hlm.

Setianingsih, E, S., Sutoyo, A\&Purwanto, E. (2014). Pengembangan model bimbingan kelompok teknik pemecahan masalah untuk meningkatkan keterbukaan diri siswa. Jurnal Bimbingan Konseling, 3 (2),

Supratiknya. (2016). Komunikasi antar pribadi tinjauan psikologis. Yogyakarta: PT Kanisius.

Tokic, A. (2010). Perental behaviors related to adolescents self-disclosure: adolescents views. Journal of Social and Personal Relationships SAGE 28 (2). 201-222.

Veletsianos, G \& Stewart, B. (2016). Discreet Openness: Scholars' Selective and Intentional Self-Disclosures Online. Social Media + Society, hlm. 1-11. 